BLS 34, No 1 2008. DOI: http://dx.doi.org/10.3765/bls.v34i1.3583

(published by the Berkeley Linguistics Society and the Linguistic Society of America)

\title{
Two Patterns of Reduplication in Washo ${ }^{1}$
}

\author{
ALAN C. L. YU \\ University of Chicago
}

\section{Introduction}

Early descriptions of Washo treat reduplication in the language as a monolithic phenomenon (Jacobsen 1964, Winter 1970; cf. Kroeber 1907): the reduplicant copies the onset of the final syllable when the root is vowel-initial (1)a, otherwise, the $\mathrm{CV}$ of the final syllable is copied and is infixed to the stressed, thus penultimate, syllable (1)b. This paper argues that Washo in fact has two patterns of reduplication, partial and full, each serves different morphosemantic functions. It is argued that forms in (1)c are in fact instances of full reduplication of $\mathrm{CV}(\mathrm{C})$ roots, distinct from the partial reduplication pattern instantiated in (1)ab. The vowel-initial forms in (1)c, to the extent they are attested, are the results of truncation that applies under restricted circumstances.

\begin{tabular}{|c|c|c|}
\hline $\begin{array}{ll}\text { a. áhad-² } \\
\text { ánkaš- } \\
\text { émc'i- }\end{array}$ & $\begin{array}{l}\text { háhad- } \\
\text { ḱánkaš- } \\
\text { c'ímc'i- }\end{array}$ & $\begin{array}{l}\text { 'across' } \\
\text { 'hollow' } \\
\text { 'wake up' }\end{array}$ \\
\hline $\begin{array}{l}\text { b. dámal- } \\
\text { bókoy- } \\
\text { Péw.šir- } \\
\text { t'é:liw- }\end{array}$ & $\begin{array}{l}\text { damámal- } \\
\text { boḱkókon- } \\
\text { Pešíw.šî- } \\
\text { t'elí:liw- }\end{array}$ & $\begin{array}{l}\text { 'to hear' } \\
\text { 'to snore' } \\
\text { 'father's brothers' } \\
\text { 'to be a man' }\end{array}$ \\
\hline
\end{tabular}

\footnotetext{
${ }^{1}$ I would like to thank the audience at SSILA 2008 and BLS 34 for their comments and suggestions. Special thanks go to Washo elders who have generously (and patiently) shared their knowledge of the language with me over the years.

${ }^{2}$ The data presented in this paper is given in a modified phonemic orthography adopted from Jacobsen 1964. In syllable-final positions, the three-way (voiced, voiceless, ejective) laryngeal contrast neutralizes toward voicelessness. Capitalized /M, W, L, Y, D/ stand for the voiceless counterparts of modal voiced sonorants. Voiced and ejective affricates are represented as $/ \mathrm{z} /$ and /c'/ respectively. Long vowels are found only in stressed syllables; short vowels can occur in any syllable. For more details on Washo stress and vowel length distribution, see Yu 2005 \& In press.
} 
Alan C. L. Yu

$$
\begin{array}{lll}
\text { c. Ínkin- } & \text { kínkin- } & \text { 'black' } \\
\text { áynay- } & \text { náynay- } & \text { 'muddy, gooey' }
\end{array}
$$

This paper is organized as follows: Section 1 introduces the main analytic puzzle, which we argue, in Section 2, is understandable if two patterns of reduplication are distinguished in Washo. Section 3 raises a complication concerning the behavior of certain fully-reduplicated forms. Section 4 resolves this complication by arguing that the apparent resemblance between the two reduplicative patterns results from a truncation process that operates on the full-reduplicated forms. Implications and conclusion are given in Section 5.

\section{Washo reduplication: the basics}

Washo is a severely moribund language spoken by approximately 13 elderly speakers in an area around Lake Tahoe, California and Nevada. Early accounts of Washo morphology recognize only one type of reduplicative morphology in the language: partial reduplication (Jacobsen 1964, Winter 1970). At its most basic form, the $\mathrm{CV}$ of the root-final syllable is copied and serves as the penultimate syllable (1)b. ${ }^{3}$ The penultimate distribution of the reduplicant can be clearly established in roots that contain an internal consonant sequence; the reduplicant is lodged before the sequence in such forms (e.g., nént'uš- $u$ 'old woman' net'unt'uš- $u$ 'old women'). The shape of the reduplicant differs when the root is vowel-initial, as already seen in (1)a. The reduplicant copies only the onset of the final syllable when the root is vowel-initial (e.g., émc'iyi ${ }^{4}$ 's/he wakes up' c'imc'iyi 'they wake up').

While the morpho-phonology of this partial reduplication pattern has been worked out in some detail (Broselow \& McCarthy 1983, Urbanczyk 1993, Winter 1970, Yu 2005), there remain important issues that are unresolved. Consider, for example, the data in (2).

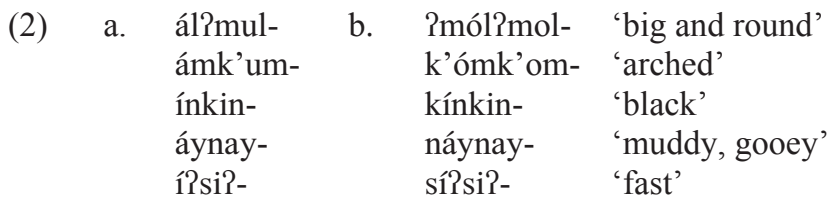

\footnotetext{
${ }^{3}$ The interpretation of partial reduplication adopted here follows that of $\mathrm{Yu} 2005$.

${ }^{4}$ Underlying vowel-initial roots are realized with an initial glottal stop phonetically. Whether a root is glottal-stop-initial or vowel-initial can be determined by the choice of the prefixal person allomorphs. For example, when a root is consonant-initial, the first person possessive prefix is $d i$ (e.g., di جá:t'u 'my older brother'); when the root is vowel-initial, the first person subject prefix is $l(E)$ - where $E$ indicates the type of vowel coloring effect the first person prefix has on the rootinitial vowel (e.g., láyuk 'my parent in law).
} 


\section{Two reduplication patterns in Washo}

What is peculiar about the data in (2) is the fact that the first and final syllables of the forms in (2)b - the presumed partially reduplicated counterparts of the vowelinitial forms in (2)a - are identical. Why might this be? Two possible explanations readily come to mind. As is assumed in previous accounts, the appearance of rootinternal syllable identity could be an accidental consequence of partial reduplication. Alternatively, syllable identity observed in (2)b might reflect a previously undocumented process of full reduplication of $\mathrm{CV}(\mathrm{C})$ roots in Washo. Upon closer examination, we found converging evidence in support of the two-pattern analysis. The next section reviews the evidence.

\section{Arguments for two reduplications in Washo}

Support for establishing a full reduplication pattern distinct from partial reduplication comes from two main sources: (i) the morphosemantic behavior of fully vs. partially reduplicated stems, and (ii) the phonotactics of fully reduplicated forms. Let us first consider the morphosemantic evidence.

\subsection{Morphosemantic distribution}

Plurality in Washo is not obligatorily marked. However, nominal plurality may nonetheless be indicated via partial reduplication (e.g., dáPa 'mother's brother' dąápa 'mother's brothers'; $p$ 'ísew 'ear' p'isésew 'ears'). When verbs are partially reduplicated, readings of pluractionality obtain. That is, the event denoted by the verb might be interpreted variously as repetitive (3)a, distributed (3)b, durative (3)c, or having multiple participants (3)d, depending on the context. For example, dámal- $i$ 's/he hears' has a multiple-experiencer reading when the verb is partially reduplicated (damámal-i 'they hear'). According to Jacobsen (1964: 530), there are instances where partially reduplicated verbs yield multiple interpretations. For example, the stem -iti?- 'down, downward' may pluralize the subject as in tuktéti?i 'they're looking down' or the object tumitétili 'he has both feet hanging down'. The verb tum?nána?i (<-ąa?- 'on') may mean either 'he has both feet on it', 'he keeps putting his foot (or both feet) on it', 'they have their feet (either one or two each) on it', or 'they keep putting their feet (either one or two each) on it'.

$$
\begin{aligned}
& \text { a. binínil- (< bínil- 'to try to') } \\
& \text { b. gepúpu?i (< ípu?- 'to find') } \\
& \text { gašášdimi (< ášdim- 'to hide') }
\end{aligned}
$$

'to try repeatedly'

'he found several things in several places' 'he's hiding things in different places'

c. duwéwe?- $(<$ dúwe?- 'to want 'to keep trying to' to, be about to')

d. méme?i (< íme?- 'to drink') 'they're drinking' šélšimi (< élšim- 'to sleep' 'they're sleeping' 
Alan C. L. Yu

The morphosemantic functions of fully reduplicated stems, henceforth F-STEMS, are far more diverse by comparison. The majority of f-stems are adjectival:

$\begin{array}{ll}\text { túltul- } & \text { 'coarse' } \\ \text { Pyín?yin- } & \text { 'varicolored' } \\ \text { púypuy- } & \text { 'thin' } \\ \text { hú:hu- } & \text { 'striped' } \\ \text { p'ťšp'iš- } & \text { 'long, narrow (of eyes)' } \\ \text { káykay- } & \text { 'long' }\end{array}$

$\begin{array}{ll}\text { šápšab- } & \text { 'fuzzy' } \\ \text { háwhaw- } & \text { 'light' } \\ \text { k'áwkaw- } & \text { 'hard' } \\ \text { Pmól?mol- } & \text { 'big and round' } \\ \text { tó?to?- } & \text { 'gray' } \\ \text { k'ómk’om- } & \text { 'arched, hunched' }\end{array}$

Many animal names are either intrinsically fully reduplicated (e.g., gówgow 'Canadian goose') or derived from f-stems. For example, the word for 'carrot', c'ilut'fnt'in, is derived from the lexical prefix c'ilu- 'hip' and the fully reduplicated adjective t'mnt'in 'wrinkled, rough'. One of the bird names, siwsiwhu, is derived from the adjective síwsiw 'smooth, slippery' and the nominalizing suffix - $h u$.

$\begin{array}{llll}\text { dezítzidi? } & \text { 'snowbird' } & \text { da2muk'áyk'ay } & \text { 'mosquito' } \\ \text { zíwziwhu } & \text { woodpecker sp. } & \text { mákmak } & \text { bird sp. } \\ \text { Pit'ónt'on } & \text { 'Jew's harp' } & \text { dewgeltúktuk } & \text { 'gasoline engine' } \\ \text { gá:zagaza } & \text { bird sp. } & \text { deyk'úyk'uyi } & \text { 'a crooked person' } \\ \text { c'élc'el } & \text { Squirrel sp. } & \text { gówgow } & \text { 'Canadian goose' }\end{array}$

Besides its adjectival and name-forming usages, full reduplication might serve certain onomatopoetic/iconic function. Full reduplication is, for example, observed in two types of verbs. One major class depicts noise generating events.

$\begin{array}{llll}\text { wákwag- } & \text { 'to bark' } & \text { ziní:ni- } & \text { 'to ring' } \\ \text { diní:ni- } & \text { 'to roar' } & \text { 2íy?ìy- } & \text { 'to sob' } \\ \text { wékweg- } & \text { 'to quack' } & \text { siyí:yi- } & \text { 'to hum' } \\ \text { wétwed- } & \text { 'to quack' } & \text { k'ótk'od- } & \text { 'to cluck' }\end{array}$

It is possible that some of the names of animals/objects contain sound-symbolic full reduplication as well. Take, for example, the names of two types of drums in Washo, Pitmukhénhen 'bass drum' and dewgebúgbug 'drum'. Both contain a fully reduplicated component.

The other class of f-stems describes semelfactive actions that prototypically occur in multiple consecutive iterations. Since all the forms in (7) are fully inflected, the f-stem is underlined for ease of reference.
(7) le?lesénseni 'it's nibbling me' tukc'ímc'imi 'he's blinking'

\footnotetext{
${ }^{5}$ This form suggests that full reduplication might not be restricted to monosyllabic roots only.
} 


\title{
Two reduplication patterns in Washo
}

\author{
tum?sópsobi 'he's splashing his feet' \\ bákbagi 'he's smoking' \\ hesípsibi it's sprinkling; raindrop'
}

While the forms in (7) involve repeated actions, they are not to be confused with the pluractional functions of partial reduplication discussed earlier, however. As argued in Wood (2007), there are two subtypes of pluractional verbs: eventinternal vs. event-external. Event-internal pluractionals prototypically are semelfactive or achievement verbs that are typically or inherently repeated. They also tend to have high degree of continuity, pertaining to a single occasion with a common goal or completion. The distribution of event-external pluractionals, on the other hand, is far less restrictive. Event-external pluractionals may be found with verbs of all Aktionzarten involving either single or multiple occasions with either a continuous or intermittent reading. Verbs with full reduplication appear to be pluractionals of the event-internal type, while verbs with partial reduplication are pluractionals of the event-external type. Further research is needed to substantiate this analysis. The morphosemantic evidence reviewed thus far, however, strongly supports differentiating the f-stems from those that participate in partial reduplication, henceforth P-STEMS. Full reduplication is found in adjectives, names of animals, instruments, and human relations, as well as verbs of noise-generating events and of event-internal repetitive actions. Partial reduplication is only observed when nouns and verbs are pluralized. The fact that fully reduplicated nouns may be partially reduplicated when pluralized (e.g., sáksak 'grandfather's brother' sasáksak 'grandfather's brothers') further supports distinguishing partial reduplication from full reduplication.

\subsection{The phonotactics of full and partial reduplications}

The morphosemantic evidence notwithstanding, there also are strong phonological reasons for analyzing the f-stems and p-stems differently. Syllables in the native Washo lexicon are maximally $\mathrm{CV}(\mathrm{C})$ in shape. ${ }^{6}$ Given the relatively simple syllable canon of Washo, the range of root-internal consonant sequences are restricted. A few phonotactic restrictions further limit the range of possible root-internal consonant sequences. To begin with, the three-way laryngeal contrast is neutralized toward the plain series in coda position (e.g., wait 'tomorrow' wardin 'now' watlí: 'morning'). Thus, the final consonants of the base and the reduplicant of the f-stem may differ in voicing (e.g., gawgap'ótp'odi 'it's crackling' vs. gawgap'ótp'othayi 'he's causing it to crackle'). ${ }^{7}$ Voiceless

\footnotetext{
${ }^{6}$ Jacobsen considers syllable-initial glottalized sonorants sequences of glottal stop plus modal voice sonorant. However, the status of glottalized sonorants as consonant cluster is currently in dispute. See Peachey (2006) for more discussion.

${ }^{7}$ Recent studies have found that many languages purported to have a voicing contrast are better analyzed as having an aspiration contrast (e.g., Petrova et al. 2006). This might be the case in Washo. The so-called "voiced" stops are rarely fully voiced word-initially; they are generally voiceless unaspirated. In intervocalic positions, the observed voicing might be better analyzed as a
} 
Alan C. L. Yu

sonorants are also never found in coda position. Given these restrictions, let us consider the set of possible post-tonic $-\mathrm{C}_{1} \mathrm{C}_{2}$ - sequences in Washo, summarized in Table 1. Of the 136 attested post-tonic consonant sequences in Washo, 106 of these post-tonic consonant sequences are found in p-stems, which include both roots that participate in partial reduplication as well as roots that do not participate in any form of reduplication at all; the set of roots that may be pluralized is limited. Although 23 of these 106 post-tonic consonant sequences are also observed in the set of f-stems, there remains 30 additional post-tonic consonant sequences that are attested only in roots with full reduplication and not elsewhere. Why should the f-stems permit a deviant set of post-tonic consonant sequence phonotactics? This outcome is to be expected given the analysis advocated here. When a CVC root is reduplicated, the coda consonant will come in contact with the first consonant of the root syllable, creating a consonant sequence that might not otherwise be attested in the non-reduplicated roots in the language. For example, the post-tonic consonant sequence $-t w$ - is only observed in fully reduplicated words such as wátwadi 'the day after tomorrow', which is derived from the root wáit 'tomorrow'.

The divergent post-tonic $-\mathrm{C}_{1} \mathrm{C}_{2}$ - phonotactics of $\mathrm{p}$-stems and f-stems highlights the morphologically complex nature of the f-stems. Consonant sequences that are not otherwise found in monomorphemic roots in Washo are nonetheless observed in the f-stems. What then is the status of the CVC roots that form the bases of the f-stems, if forms such as /wekweg/ 'to quack' are supposed to be derived from the full reduplication of /weg/? For the majority of f-stems, the corresponding $\mathrm{CV}(\mathrm{C})$ bases are not free standing. Thus, the synchronic status of these monosyllabic roots is open to debate. Languages with frozen fully reduplicated forms are not uncommon, however. Scholars have often recognized their special status and have generally assumed that such forms are derived from some simplex base forms (Bat-El 2006, Buckley 1997, Rose 1997). To be sure, while the synchronic status of the monosyllabic roots might be questionable, the productivity of full reduplication per se is not in doubt. Recent loanwords may undergo full reduplication, as evidenced by the adaptation of English 'ball' as bólbol 'spherical' in Washo. Also, certain time expressions are transparently derived from full reduplication (e.g., Rlót 'yesterday' $\sim$ Rlót?lodi 'the day before yesterday'; wá:t 'today' wátwadi 'tomorrow').

matter of passive voicing. If such an analysis is proven correct for Washo, then the final consonants of the base and the reduplicant of roots such as /wa:d/ is better analyzed as /wa:t/. 
Two reduplication patterns in Washo

\begin{tabular}{|l|l|l|l|l|l|l|l|l|l|l|l|l|l|}
\hline $\mathrm{p}$ & $\mathrm{t}$ & $\mathrm{k}$ & $\mathrm{l}$ & $\mathrm{s}$ & $\mathrm{s}$ & $\mathrm{h}$ & $\mathrm{m}$ & $\mathrm{n}$ & $\mathrm{y}$ & $\mathrm{l}$ & $\mathrm{W}$ & $\mathrm{y}$ & \\
\hline & & & & & & & $\mathrm{x}$ & & & & & & $\mathrm{p}$ \\
\hline $\mathrm{x}$ & & $\mathrm{x}$ & & & & & & $?$ & & & $?$ & $?$ & $\mathrm{t}$ \\
\hline & & & $\mathrm{x}$ & & & & & & $\mathrm{x}$ & $\mathrm{x}$ & $?$ & & $\mathrm{k}$ \\
\hline $\mathrm{x}$ & $\mathrm{x}$ & & $\mathrm{x}$ & & & & $\mathrm{x}$ & & & $\mathrm{x}$ & $\mathrm{x}$ & & $\mathrm{b}$ \\
\hline $\mathrm{x}$ & $\mathrm{x}$ & $\mathrm{x}$ & $\mathrm{x}$ & $\mathrm{x}$ & $\mathrm{x}$ & & $\mathrm{x}$ & $\mathrm{x}$ & & $\mathrm{x}$ & $\mathrm{x}$ & $\mathrm{x}$ & $\mathrm{d}$ \\
\hline & $\mathrm{x}$ & $\mathrm{x}$ & $\mathrm{x}$ & $\mathrm{x}$ & $\mathrm{x}$ & & $\mathrm{x}$ & & $\mathrm{x}$ & $\mathrm{x}$ & $\mathrm{x}$ & & $\mathrm{g}$ \\
\hline & & $?$ & & $\mathrm{x}$ & & & $\mathrm{x}$ & $?$ & $\mathrm{x}$ & & & $\mathrm{x}$ & $\mathrm{Z}$ \\
\hline & $\mathrm{x}$ & & & & $\mathrm{x}$ & & $\mathrm{x}$ & & & & & & $\mathrm{p}$ \\
\hline $\mathrm{x}$ & & & & $\mathrm{x}$ & & & $\mathrm{x}$ & $\mathrm{x}$ & & $\mathrm{x}$ & & $\mathrm{x}$ & $\mathrm{t}$ \\
\hline & & & & & & & $\mathrm{x}$ & $\mathrm{x}$ & & & & $\mathrm{x}$ & $\mathrm{c}$ \\
\hline & $\mathrm{x}$ & & & & & & $\mathrm{x}$ & $\mathrm{x}$ & $\mathrm{x} ?$ & & & $\mathrm{x}$ & $\mathrm{k}$ \\
\hline $\mathrm{x}$ & $\mathrm{x}$ & $\mathrm{x}$ & $\mathrm{x}$ & & & & $\mathrm{x}$ & & $\mathrm{x}$ & $?$ & & & $\mathrm{~s}$ \\
\hline & & $\mathrm{x}$ & $\mathrm{x}$ & & & & $\mathrm{x}$ & & & $\mathrm{x}$ & $\mathrm{x}$ & $\mathrm{x}$ & \multicolumn{5}{c|}{} \\
\hline & & & & & & & $\mathrm{x}$ & & & $?$ & $\mathrm{x}$ & $\mathrm{x}$ & $\mathrm{h}$ \\
\hline & & & $\mathrm{x}$ & $\mathrm{x}$ & $\mathrm{x}$ & $\mathrm{x}$ & & & & $\mathrm{x}$ & & $?$ & $\mathrm{~m}$ \\
\hline & & & $\mathrm{x}$ & & & & & & & & & & $\mathrm{n}$ \\
\hline & & & $\mathrm{x}$ & & & & & & & $\mathrm{x}$ & $\mathrm{x}$ & $\mathrm{x}$ & $\mathrm{y}$ \\
\hline & $\mathrm{x}$ & & $\mathrm{x}$ & & $\mathrm{x}$ & $\mathrm{x}$ & $\mathrm{x}$ & & $\mathrm{x}$ & & $\mathrm{x}$ & $?$ & $\mathrm{l}$ \\
\hline & & $\mathrm{x}$ & $\mathrm{x}$ & & & & & & & $\mathrm{x}$ & & $\mathrm{x}$ & $\mathrm{w}$ \\
\hline & $\mathrm{x}$ & & $\mathrm{x}$ & & & & $\mathrm{x}$ & & & & & & $\mathrm{y}$ \\
\hline & & & & & & & & & & $\mathrm{x}$ & & & $\mathrm{M}$ \\
\hline & & & & & & & & & & & $\mathrm{x}$ & & $\mathrm{L}$ \\
\hline
\end{tabular}

Table 1 . The inventory of all possible post-tonic $C_{1} C_{2}$ sequences in Washo. The set of possible $\mathrm{C} 1$ consonants is presented horizontally (in columns) while the set of possible $\mathrm{C} 2$ is given vertically (in rows). The symbol " $\mathrm{x}$ " indicates $\mathrm{C}_{1} \mathrm{C}_{2}$ sequences observed in native Washo monomorphemic roots; consonant sequences only found in Washo proper names are marked as "?"; consonant sequences attested in fully reduplicated forms are indicated by the shaded cells.

\section{Discussion}

Now that we have established that certain reduplicated stems are the product of full reduplication while others are that of partial reduplication, a new set of base-reduplicant relationship emerges. That is, in the case of partial reduplication, the relationship between the reduplicant and the base remains unchanged: the reduplicant is $\mathrm{CV}$ when the penultimate syllable of the base is consonant-initial; the reduplicant is $\mathrm{C}$ when the base form is disyllabic and vowel-initial. However, in the case of full reduplication, the base is presumably underlyingly $\mathrm{CV}(\mathrm{C})$ in shape. The reduplicant copies the entire base form. A summary of these two reduplicative patterns is given in (8). 
Alan C. L. Yu

(8)

a. Partial reduplication

$P$-stems

$\mathrm{C}_{1} \mathrm{~V}(\mathrm{X}) \mathrm{C}_{2} \mathrm{~V}\left(\mathrm{C}_{3}\right)$

nént'uš- 'to be an old woman'

$\mathrm{V}(\mathrm{X}) \mathrm{C}_{1}(\mathrm{~V})\left(\mathrm{C}_{2}\right)$

élšim- 'to sleep'

b. Full reduplication

$\mathrm{CV}(\mathrm{C})$-roots

$\mathrm{C}_{1} \mathrm{~V}\left(\mathrm{C}_{2}\right)$

-nay- $\rightarrow \quad$ Pluralized p-stems

$\mathrm{C}_{1} \underline{\mathrm{V}}_{1} \underline{\mathrm{V}}(\mathrm{X}) \mathrm{C}_{2} \mathrm{~V}\left(\mathrm{C}_{3}\right)$

net'únt'uš- 'to be old women'

$\underline{\mathrm{C}}_{1} \mathrm{~V}(\mathrm{X}) \mathrm{C}_{1}(\mathrm{~V})\left(\mathrm{C}_{2}\right)$

šélšsim- '(pl.) to sleep'

$\rightarrow \quad$ F-stems

$\mathrm{C}_{1} \mathrm{~V}\left(\mathrm{C}_{2}\right) \mathrm{C}_{1} \mathrm{~V}\left(\mathrm{C}_{2}\right)$

náynay- 'muddy, gooey'

This two-pattern analysis of reduplicative morphology in Washo gives rise to a curious puzzle. As the data in (2) suggests, fully reduplicated forms actually have $\mathrm{V}\left(\mathrm{C}_{2}\right) \mathrm{C}_{1} \mathrm{~V}\left(\mathrm{C}_{2}\right)$ counterparts akin to the vowel-initial p-stems in (1)a. Previous analyses took these vowel-initial f-stems as nothing more than the non-pluralized counterparts of f-stems. Thus, according to Jacobsen (1964), the base form of náynay 'muddy, gooey' is -áynay (p. 329); the base form of p'ilp'il 'blue' is -ilp'il (p. 336). The fact that the f-stems resemble products of full reduplication was considered epiphenomenal under Jacobsen's analysis. What is the status of these vowel-initial f-stems (henceforth VF-STEMS) under the current analysis? As will be demonstrated in the next section, the nature of the vf-stems becomes apparent when the distribution of the vf-stems is viewed within the context of Washo verbal morphology: vf-stems are the dependent version of the more freely occurring f-stems, derived via a process of truncation.

\section{Dependent-stem truncation}

As argued in Jacobsen's (1980) seminal paper, many verb stems in Washo are bipartite. That is, many stems are decomposable into two components, the lexical prefix and the dependent stem. What is crucial for the present purpose is the notion of the dependent stem. Dependent stems are bound morphemes that have concrete meanings and must combine with either a lexical prefix or another stem in order to be realized. For example, the stem -ígel 'around something, around in a circle' may combine with a multitude of lexical prefixes:

(9) Mú:gel- 'to run around something, around in a circle'

beyú:gel- 'to flow around in a circle (as in a whirlpool)'

hú:gel- 'to mix up, scramble with side of long object'

yú:gel- 'to wind something around something'

múrgel- 'to stir'

me?bú:gel- 'to be dizzy' 


\section{Two reduplication patterns in Washo}

Likewise, the lexical prefix $d u l^{2}-$ "with hand, arm, descriptive of hand, paw' ${ }^{8}$ may occur with a variety of dependent verb stems:

$\begin{array}{ll}\text { dulá:š- } & \text { 'to have one's hand in something' } \\ \text { dulé:k'ill- } & \text { 'to cook'; literally 'to swing one's arm around' } \\ \text { duléšil- } & \text { 'to offer one's hand to someone' } \\ \text { dulakákd- } & \text { 'to move hands slowly' } \\ \text { dule?wí?wid- } & \text { 'to wave' } \\ \text { dulé:ti?- } & \text { 'to hold his hand down' } \\ \text { dulepépeš- } & \text { 'to have black, dirty, greasy hands' }\end{array}$

An important generalization concerning the vf-stems is that they are only observed as dependent stems in bipartite constructions.

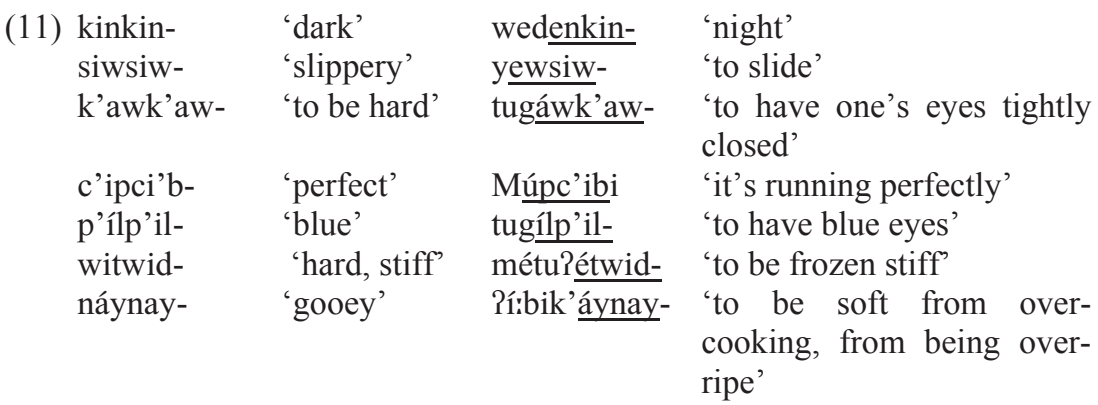

The f-stems, on the other hand, are never found in this context; they are readily observable in the predicative adjectival construction, however (e.g., Pilc'ipc'ibi?i 'it's perfect'). Why do vf-stems only appear as dependent stems while their supposed partially reduplicated f-stem counterparts appear in the complementary contexts? To be sure, genuine p-stems can function as dependent stems whether they are partially reduplicated or not (12).

$\begin{array}{ll}\begin{array}{l}\text { P-stem } \\ \text { ipeš- 'rotten' }\end{array} & \begin{array}{l}\text { Dependent p-stem } \\ \text { dúpeš- 'to be blacken by } \\ \text { sunlight' }\end{array} \\ \text {-iti?- 'down' } & \begin{array}{l}\text { Dependent pluralized p-stem } \\ \text { dulepépeš- 'to have black, } \\ \text { dirty, greasy hands' }\end{array} \\ \text { crash' } & \text { to fall with a } \begin{array}{l}\text { tuktéti?i 'they're looking } \\ \text { down' } \\ \text {-ips- 'up, lift' }\end{array}\end{array}$

\footnotetext{
${ }^{8}$ The symbol $\left[{ }^{\vee}\right]$ indicates the presence of a floating mora that docks onto the stressed syllable if the stressed syllable is open.
} 
Alan C. L. Yu

Also, p-stems often can appear both within and outside the confine of the dependent stem position. For example, the verb -ihuk'- '(to be) dry' may appear freely on its own, as in Ríhuk'i 'it's dry'. The same verb may occur with a few lexical prefixes expressing manner of drying, such as lé:huk'- 'to dry by wiping, mopping' vs. séhuk'- 'to put out to dry'. More importantly, -ihuk'- may also function as the first part of a bipartite stem (e.g., Pihuk'eti?- 'to get dry', literally, 'to dry down'; Píhuk'étwid- 'to be dry, stale, and stiff (e.g., bread)'; Píhuk'átp'udi 'it's dry and crumbly'). Thus the fact that vf-stems can only appear as dependent stems in bipartite structures cannot be attributed to any intrinsic properties of dependent stems. Likewise, that the f-stem cannot serve as dependent stems does not fall out from the morphosyntatic properties of partial reduplication.

Here, we propose to relate the vf-stems to the f-stems by way of a truncation process. The truncation process eliminates the first consonant of an f-stem. A schematic summary of the relationship between the different types of reduplicative morphology as well as the truncation process is given in (13).

a. Partial reduplication

$$
\begin{array}{lll}
\text { P-stems } & & \text { Pluralized p-stems } \\
\mathrm{C}_{1} \mathrm{VC}_{2} \mathrm{~V}\left(\mathrm{C}_{3}\right) & \rightarrow & \mathrm{C}_{1} \underline{\mathrm{C}}_{1} \underline{\mathrm{VC}} \mathrm{C}_{2} \mathrm{~V}\left(\mathrm{C}_{3}\right) \\
\mathrm{VC}_{1} \mathrm{~V}\left(\mathrm{C}_{2}\right) & \rightarrow \quad \underline{\mathrm{C}}_{1} \mathrm{VC} & \mathrm{V} \\
\end{array}
$$

b. Full reduplication

$$
\begin{aligned}
& \mathrm{CV}(\mathrm{C}) \text {-roots } \\
& \text { F-stems } \\
& \mathrm{C}_{1} \mathrm{~V}\left(\mathrm{C}_{2}\right) \quad \rightarrow \quad \mathrm{C}_{1} \mathrm{~V}\left(\mathrm{C}_{2}\right) \mathrm{C}_{1} \mathrm{~V}\left(\mathrm{C}_{2}\right) \\
& \text { Vf-stems } \\
& \rightarrow \quad-\mathrm{V}\left(\mathrm{C}_{2}\right) \mathrm{C}_{1} \mathrm{~V}\left(\mathrm{C}_{2}\right)
\end{aligned}
$$

Dependent-stem formation

What is the nature of this truncation process? To understand its source, it is important to first understand the phonotactics of the dependent stems. All dependent stems are vowel-initial. A quick examination of all reduplicable stems surveyed in Jacobsen 1964 will illustrate this point more clearly. Out of the 117 reduplicable stems examined, 38 are nouns and 69 are verbs. Within the set of verbs, it can be further decomposed into verbs that may only be used as dependent verbs (which all vf-stems belong) and those that have no restricted usage. As summarized in (14), while the non-dependent verbs are almost evenly split between being $\mathrm{C}$-initial and $\mathrm{V}$-initial, all dependent verb stems are vowel-initial. Nouns, on the other hand, are overwhelmingly consonant-initial.

\begin{tabular}{|l|l|l|l|}
\hline & C-initial & V-initial & Total \\
\hline Verb (free) & 15 & 12 & 27 \\
\hline Verb (dependent) & 0 & 52 & 52 \\
\hline Noun & 37 & 1 & 38 \\
\hline
\end{tabular}

The data in (14) suggests that C-reduplication mainly applies to vowel-initial verbs; the only vowel-initial noun has irregular plural form (-áyuk 'parent-in-law' vs. yó:k 'parents-in-law'). That dependent stems must be vowel-initial is further 


\section{Two reduplication patterns in Washo}

confirmed by an examination of the 94 dependent stems surveyed in Jacobsen 1980. 91 are vowel-initial. The ones that are not vowel-initial, bélbel- 'high (of voice)', sílu- '(speech) hard to understand, with foreign accent' and t'át'ad 'rattling', appear to attach to prefixes that only take C-initial stems. Such prefixes (e.g., the attributive 2il-; classifier-plural marking $w g V$-) might not be lexical prefixes, however. Non-lexical prefixes in Washo (e.g., the instrumental nominalizing prefix Pit-) do not take a dependent-stem as its right-sister. Thus, if this interpretation is correct, there is no exception to the vowel-initial generalization of dependent stems. What this suggestion is that truncation of the initial consonant of f-stems might be triggered by structural analogy to the predominance of vowel-initial dependent stems.

\section{Conclusion}

To summarize, this paper establishes that there are two types of reduplicative morphology in Washo. Fully reduplicated stems exhibit different morphosyntactic functions and phonotactic properties than those with partial reduplication. The vf-stems are derived from a process of dependent stem truncation. This truncation process appears to be motivated by the fact that the phonotactics of dependent stems are invariably vowel-initial. Thus when an f-stem is used in a bipartite construction, by analogy to all other dependent stems, the initial consonant of the $\mathrm{f}$-stem is eliminated, rendering the dependent f-stem vowel-initial. This pattern of truncation is unique among truncation processes cross-linguistically. As Weeda (1992: Section 1.3) points out, subtractive aphaeresis - the elimination of the beginning of a string (thus keeping the end) where the truncated portion is of a certain size/shape - generally have limited functionalities. In particular, all identified instances of subtractive aphaeresis, notes Weeda, furnish word variants and are only pragmatically distinctive; subtractive aphaeresis does not appear to ever be used derivationally. The uniqueness of Washo dependent-stem truncation might stem from the fact that truncation itself is not motivated by prosodic reasons, as truncation patterns generally are; instead, it emerges as a result of structural analogy motivated by the fact that all dependent-stems are vowel-initial.

\section{References}

Bat-El, Outi. 2006. Consonant identity and consonant copy: The segmental and prosodic structure of Hebrew reduplication. Linguistic Inquiry 37(2): 179-210.

Buckley, Eugene. 1997. Tigrinya root consonants and the OCP. Penn Working Papers in Linguistics 4.3, 19-51.

Broselow, E, and J. McCarthy. 1983/1984. A theory of internal reduplication. Linguistic Review 3:25-88.

Jacobsen, William H. Jr. 1964. A grammar of the Washo language. PhD diss., Department of Linguistics, University of California, Berkeley. 
Alan C. L. Yu

Jacobsen, William Jr. 1980. Washo bipartite verb stems. In K. Klar et al., eds., American Indian and Indoeuropean Studies: Papers in honor of Madison S. Beeler. The Hague: Mouton. 85-99.

Kroeber, A. L. 1907. The Washo language of East Central California and Nevada. University of California Publication on American Archaeology and Ethnography 4\&5. Berkeley: The University Press.

Peachey, Robert. 2006. Glottalized resonant in Washo. MA thesis, University of Chicago.

Petrova, O., R. Plapp, C. Ringen, and S. Szentgyörgyi. 2006. Voice and Aspiration: Evidence from Russian, Hungarian, German, Swedish, and Turkish. The Linguistic Review 23: 1-25.

Rose, Sharon. 1997. Theoretical issues in comparative Ethio-Semitic phonology and morphology. PhD diss., McGill University, Montreal.

Urbanczyk, Suzanne C. 1993. Infixing and moraic circumscription. In Tim Sherer, ed., Phonological representations. University of Massachusetts Occasional Papers 16. 319-357.

Weeda, Donald. 1992. Word truncation in Prosodic Morphology. PhD diss., University of Texas at Austin.

Winter, Werner. 1970. Reduplication in Washo: A restatement. International Journal of American Linguistics 35:190-198.

Wood, Esther. 2007. The semantic typology of pluractionality. $\mathrm{PhD}$ diss., University of California, Berkeley.

Yu, Alan C. L. 2005. Quantity, stress, and reduplication in Washo. Phonology 22(3): 437-475.

$\mathrm{Yu}$, Alan C. L. In press. The phonetics of quantity alternation in Washo. Journal of Phonetics.

Alan C. L. Yu

1010 E $59^{\text {th }}$ Street

University of Chicago

Chicago, IL 60637

aclyu@uchicago.edu 